\title{
Article
}

Ebba Henrekson*, Fredrik O. Andersson, Filip Wijkström and Michael R. Ford

\section{Civil Society Regimes and School Choice Reforms: Evidence from Sweden and Milwaukee}

https://doi.org/10.1515/npf-2019-0042

Received July 2, 2019; accepted March 19, 2020

\begin{abstract}
We examine the effects of school choice reforms implemented in the early 1990s in two different settings: Sweden and Milwaukee (WI, U.S.). We show how both the ideological and theoretical arguments for choice reform were similar in the two contexts, yet the consequences in terms of the organizational outcome and institutional sector configuration ended up strikingly dissimilar. While the new group of actors in the Swedish school system consisted primarily of large-scale for-profit schools, with only a minor share of the expansion being catered to by nonprofit actors, the Milwaukee school choice program became dominated by small-scale nonprofit schools operated by religious communities. We seek to explicate these differences by drawing on the welfare state literature and social origins theory, as well as from organizational and historical institutional theory. We argue that the resulting composition of providers is directly related to the deep-seated differences in the civil society regimes operating in the two contexts.
\end{abstract}

Keywords: civil society regime, school choice, new public management, nonprofit schools, faith-based organizations, education

\footnotetext{
*Corresponding author: Ebba Henrekson, Ersta Sköndal Bräcke University College, Stockholm, 100 61, Sweden, E-mail: ebba.henrekson@esh.se. https://orcid.org/0000-0002-8178-2993 Dr. Fredrik 0. Andersson: Indiana University-Purdue University Indianapolis, O'Neill School of Public and Environmental Affairs, Indianapolis, IN, 46202-5199, USA

Dr. Filip Wijkström: Management \& Organization, Stockholm School of Economics, Box 6501, Stockholm, SE 113 83, Sweden

Dr. Michael R. Ford: University of Wisconsin Oshkosh, Oshkosh, WI, USA
} 


\section{Introduction}

The high importance of education to a well-functioning society is widely accepted. At the same time, education is a major battlefield for social and political ambitions. By changing the basic conditions for the actors in this field, for example through the introduction of new educational policies or alternative models for funding, novel ideas are launched with the aim to transform the long-term trajectory of entire societies. Historically, a diversity of systems and models across the world has been adopted for how to organize, manage, provide, fund and distribute education, as in many other welfare fields. However, it has been argued that increased globalization "creates many pressures and opportunities for structuring and standardizing national and local societies, and thus produces waves of conformity with worldwide models" (Meyer 2007:261). One important vehicle for this development toward conformity is often argued to be the transnational spread of ideas and ideals through new concepts and models (Finnemore and Sikkink 1998).

Scholars have argued that different models aimed at achieving "a good society" are increasingly and strikingly isomorphic (Meyer 2007; Meyer et al. 1997). The rise and spread of the New Public Management (NPM) agenda in the early 1980s is one example of how such a package of ideas can gain isomorphic currency and spread across the world. NPM models have already altered how key welfare services are organized and provided in many countries (Blomqvist 2004; Kettl 2005). Recent work by (Ford and Andersson 2019), for example, specifically illustrates how the structure of school choice programs creates isomorphism within NPM-style reform, while Wilkins et al. (2019) point to similar patterns among a set of countries regarding the implementation of new instruments for school governance.

The influence of NPM-inspired models across different institutional sectors in society has been conceptualized as "blurring" sector boundaries (Bromley and Meyer 2015), and the results have been described as a "mixed economy" of welfare (Pinker 1992; Powell 2007). Following the core principles of NPM, different parts of the public sector should be made more "business-like", and efficiency should be improved by implementing management models inspired by the for-profit sector and by introducing more competition via market mechanisms (Hood 1991; Kaboolian 1998; Osborne and Gaebler 1993). This trend toward more "business-like" inspiration and behavior flowing from the NPM tradition has also been observed in the nonprofit sector (Maier, Meyer and Steinbereitner 2014; Wijkström 2011). One policy area where NPM models and policies have had a significant impact worldwide is the field of education (Ford and Ihrke 2018; West and Nikolai 2017; Wilkins et al. 2019).

However, education reform efforts that shift public education away from centralized bureaucracies and toward decentralized school networks come in 
many forms. Charter schools, education savings accounts, and school voucher policies all fall under the umbrella of school choice. As Ford and Andersson (2016, 2017) have shown in previous research, there is great variation in the design of school choice policies and the specific organizations that participate in them. As such, understanding the universal voucher program-specific impacts of school choice policies requires comparative analysis. In line with the most different case studies approach (see Gerring 2007), we present a comparison of the consequences of two school choice policies with voucher system solutions in two different contexts: the country of Sweden and the U.S. City of Milwaukee.

\subsection{The Purpose of the Article}

In this article, we draw on organizational ecology and NPM literature in a comparative case study of the implementation and evolution of school choice policy reforms in the city of Milwaukee, Wisconsin, in the U.S. and in the country of Sweden. Both programs are longstanding and, though similar in concept, differ in both their evolution over time (1992-2018) and the context in which they operate. Inspired by Milton Friedman's (1955) market-based theory of education, Milwaukee and Sweden were two of the earliest adopters of voucher-based education reforms. At first glance, the implementation of this new system for educational funding seems to have resulted in similar outcomes in the two contexts, as the number of independent state-funded schools has grown substantially in both these settings. However, when unpacking and studying the two cases in depth, one realizes how the actual outcomes are curiously dissimilar.

The purpose of this article is to examine how these two cases differ and show how their differences can be attributed to their specific institutional contexts. Sweden is a country where school choice reforms are impactful in both urban and rural areas, whereas Milwaukee is a U.S. city with approximately 600,000 residents. However, the two reforms share the commonality of being early adopters. As such, we use their conceptual similarity but contextual differences to answer the following question: what are the mechanisms, actors, and contextual and historical factors contributing to the differences in the organizational outcomes of the school choice reforms in our two different settings? More specifically, the article explains why these two particular education systems - despite some initial and important similarities in the basic setup of the introduced policies - ended up being so different.

Despite the growth in school choice policies over the past three decades, few similar comparative studies of this type have been conducted. Most other studies reviewed focus on the effects of these policies on educational quality and students' educational outcomes at independent schools (e. g., Carnoy 1998; Dronkers and Robert 
2008; McEwan 2002). These previous studies have primarily focused on the student as the unit of analysis, as opposed to the organizations or actors providing education. Other comparative research on the topic has focused on the association between policy goals and differing institutional configurations and regulatory frameworks (West 2014; West and Nikolai 2017) and the role of politics, partisanship, and welfare regimes in school marketization reforms (Hicks 2015; Klitgaard 2007, 2008).

\section{The Importance of Civil Society Regimes}

One of the most influential theories for conducting comparative welfare (state) research was developed by Esping-Andersen (1990) in the late 1980s (see also Emmengger et al. 2015, for a special issue devoted to the 25th anniversary of Esping-Andersen's seminal work The Three Worlds of Welfare Capitalism). EspingAndersen uses the concept of welfare regimes to compare and contrast the configurations of different clusters of welfare states. In this article, drawing on the complementary work by Salamon and Anheier (1998, 2006; Anheier 2010) and colleagues under the label of social origins theory developed in the Johns Hopkins Nonprofit Sector Project, we follow their example by paying specific attention to the nonprofit or voluntary sector. At the same time, however, we propose an analytical expansion in perspective to go beyond the more narrow focus on welfare inherent in both sets of theory by applying both broader and deeper civil society regime lenses in our analysis, developed in more detail below.

\subsection{From Welfare Regimes...}

Esping-Andersen (1990) describes in his seminal work how path dependency via trajectories of different historical forces formed distinctly different clusters of welfare states. The theory distinguishes between the "liberal", "corporative", and "social-democratic" welfare models; each of the regimes entails qualitatively different relationships between the state, the market, and the family. Sweden is identified as a social-democratic welfare state regime. In this regime type, Esping-Andersen argues, the principles of universalism and de-commodification of social rights have been extended to include the whole population. This formula includes the introduction of universalistic welfare programs designed to satisfy the needs, wants, and expectations of all strata of the population. The social-democratic regime crowds out market actors as well as the individual dependency of both the family and the Church in the provision of welfare. The result is a society where a majority of welfare services are funded 
and provided by the public sector. The U.S., on the other hand, is identified by Esping-Andersen as a liberal welfare regime, which is characterized by modest universal transfers, means-tested assistance, and modest social insurance schemes. The public welfare programs in this regime cater mainly to a poorer subset of the population comprising the lower strata. Market actors are often encouraged in one of two ways: (i) by the state guaranteeing only a minimum of welfare services, thereby opening up for private actors when better-off segments of the population want to top up their welfare, or (ii) by actively subsidizing private (market-based) welfare schemes.

Esping-Andersen's regime theory has been criticized for failing to account for the changes that have taken place within many welfare states in recent decades. Given that in some important dimensions, countries do conform to worldwide policy trends and adopt similar policy models for an increasing number of areas (cf. Meyer 2007), some scholars argue that welfare states might be moving out of their "regime containers" (Henriksen, Smith, and Zimmer 2012). Other scholars argue that countries borrow and translate concepts and policies across regimes, such as when social-democratic Sweden borrows the idea of a "compact" between the government and the voluntary sector from liberal England (Johansson and Johansson 2012; Reuter, Wijkström, and von Essen 2012), adding to the isomorphic patterns. Hence, welfare states facing similar difficulties might depart from their "internal" path dependencies by opting for similar solutions and policy prescriptions, as indicated above in the processes of isomorphism rolling over the globe, not the least policies influenced by the influential NPM tradition. As mentioned earlier, an increasing number of countries in the last 30 years have been adapting policies influenced by NPM practices. This has led researchers to discuss and theorize what has become known as the new "welfare mix" or "social care mix". In this new social care "mix", public entities, nonprofit actors, and commercial actors coexist in the welfare arena and even compete to provide services (Blomqvist and Winblad 2019). However, the configuration of the social care mix has been noted to differ significantly from country to country and within different policy areas (Zimmer and Evers 2010).

Another major critique of Esping-Andersen's theory of welfare state regimes, as well as other welfare state theories, is that they treat the nonprofit sector as a "residual category" (Salamon and Anheier 1998: 224) at best. This is particularly true for the case of Sweden and the other Nordic or Scandinavian countries, where popular descriptions of the organization of welfare services have simply neglected services and efforts provided by nonprofit or voluntary organizations (Lundström and Wijkström 1997; Svedberg and Olsson 2010). In the early work of Esping-Andersen, the role of civil society and nonprofit organizations (Npos) as providers of welfare services is not even 
mentioned (Kuhnle and Selle 1992). In later work, the role of the nonprofit sector and civil society appears in footnotes (Esping-Andersen 1996, 1999, 2003).

\section{2 ... Via Social Origins Theory...}

To explain differences found in the role and size of the nonprofit sector across nations, Salamon and Anheier (1998) developed what they refer to as the "social origins theory". This theory takes Esping-Andersen's theory of welfare state regimes as one of its most important starting points but moderates that theory to better incorporate the role and importance of the nonprofit or voluntary sector. The foundational premise of social origins theory is that Npos are firmly embedded in prevailing social and economic structures rather than floating freely in social space.

Moreover, and on a more general level, the social and economic structures of nations must be understood as being shaped by historical forces of "complex interrelationships among social classes and social institutions" (Salamon and Anheier 1998: 226). With the social origins theory, the authors identify four types of "nonprofit regimes": the "statist", the "liberal", the "corporatist", and the "social-democratic" regimes (Salamon and Anheier 1998: 228). Each nonprofit regime is characterized by a particular role of the state and a particular position of the nonprofit sector. The nonprofit regime types are divided along two key dimensions: first, the extent of government social welfare spending and, second, the relative size of the nonprofit sector as measured in terms of employment. This division creates a matrix incorporating the four nonprofit regime types. Each regime type has a unique configuration of public spending and relative nonprofit sector size.

The U.S. is considered to belong to the liberal cluster of nations, according to social origins theory. This model is, according to the authors, characterized by low levels of government spending on welfare services and a relatively large nonprofit sector in terms of employees. In this model, strong working-class movements or opposition from traditional elite groups have either never existed or been held at bay. The result is a significant and widespread ideological hostility and political suspicion in society toward government interference in the production of welfare services and, consequently, a preference for nonprofit alternatives. The socialdemocratic model, to which Sweden belongs, is at the opposite extreme in the nonprofit regime matrix (Lundström and Wijkström 1997). Public welfare is largely financed by public means and administered by public agencies, and as a result, nonprofit welfare producers have been crowded out. Typically, working-class 
elements, in coalition with other social classes, have been able to exercise significant political power in this type of model (Salamon and Anheier 1998).

\section{3 ... To Civil Society Regimes}

Social origins theory has been criticized, and civil society scholars have offered additions and developments to this theory to address the limitations they perceive in this approach (see, e. g., Kabalo 2009; Steinberg and Young 1998). One important addition in this line of thinking is the realization that the complexity of the institutionalized governance arrangements in a specific country is a crucial part of this kind of regime analysis (Enjolras 2009). Further, it is important to note that even if the welfare share of the nonprofit sector is a salient indicator of the importance of the sector in some countries, it does not necessarily entail that the size of organized civil society is limited overall. In fact, it has been documented that the size, role, composition, and position of civil society as a whole - voluntary, nonprofit or third sector, all depending on the national context - vary substantially between countries (Archambault, Zimmer, and Priller 2014; Sivesind and Saglie 2018; Kendall and Knapp 1996; Neumayr et al. 2009; Wijkström 1997; Wijkström and Zimmer 2011).

The U.S. and Sweden differ not only in terms of the relationship between the state, the market, and the family, as described by Esping-Andersen (1990), or in terms of the scale of the nonprofit sector, as measured by nonprofit welfare service delivery (Salamon and Anheier 1998). Both the role and the configuration of civil society are also fundamentally different in the two contexts. In the U.S., churches, human service organizations, hospitals, and foundations constitute the bulk of civil society; moreover, educational institutions such as schools comprise approximately 17 percent of the nonprofit sector. In contrast, Swedish civil society is dominated by membership-based mass associations with an internal democratic structure and an explicitly political purpose (Lundström and Wijkström 2012; Trägårdh 2010). In fact, Sweden, along with the rest of the Nordic countries, has been noted as having a sizeable and vibrant civil society (Jeppsson Grassman and Svedberg 2007; Lundström and Wijkström 1997).

Anheier and Salamon (2006) further note that their employment measurement is somewhat crude and they illustrate this by arguing that even if Sweden has one of the smallest nonprofit sectors in terms of paid employment, this fact drastically changes when the nonprofit sector scale is instead measured by, for instance, total work force, including volunteer time (see also Wijkström 1997). Nevertheless, the core analysis following social origins theory primarily focuses on the welfare 
dimensions of the nonprofit sector. The analysis includes a mix-up of the entire nonprofit sector with the welfare service-providing segments of the sector, which distorts the more general analysis. Restricting the focus too narrowly on serviceproducing Npos limits the possibilities for a more all-encompassing analysis of why specific policies play out differently depending on the national context. While remaining sympathetic to the general idea of the social origins theory, to remedy the overly narrow - welfare-dominated - analytic frame, we argue that a broader concept of a civil society regime stretching beyond the provision of welfare is more productive. We apply this broader concept in this article. Now, we turn to the parallel development of the school choice reform in Milwaukee and Sweden.

\section{The History of the School Choice Reforms in Milwaukee and Sweden}

As noted in the introduction, new education systems based on school vouchers were implemented contemporaneously in Milwaukee and Sweden at the beginning of the 1990s. In this section, we discuss the theoretical foundation for school vouchers and offer a brief outline of the historical background of the education systems in our two cases, highlighting key aspects leading up to the reforms.

The theoretical roots of school vouchers and school choice can be traced back to an essay by Chicago economist Milton Friedman from the mid-1950s (Friedman 1955). In his essay, Friedman suggests that the government should provide vouchers to parents to subsidize the cost of their children's schooling. Parents would then be free to use the voucher to purchase educational services from a school of their choice, whether operated by local public authorities, a religious order, a business enterprise, or a nonprofit organization. The government's role would be to assure "that the schools met certain minimum standards" (p. 127). If implemented, a system of school vouchers would incentivize the formation of new schools and boost competition, ultimately leading to the creation of an efficient market for education (Friedman 1955).

Although Friedman's proposal for vouchers initially failed to gain traction, it gained new momentum in the political and academic spheres during the 1980s and 90s. The rediscovery of the voucher and school choice concepts coincided with the call to reinvent government and the emergence of NPM, which seeks to challenge and change the institution of government by injecting competition, accountability, and flexibility into a public sector criticized as overly bureaucratic, rule-laden, and unresponsive to citizens (Osborne and Gaebler 1993; Osborne and Plastrik 1997; Kaboolian 1998). Since then, the idea of school choice and school vouchers has 
become a global phenomenon, and with it, the number of market-driven models of public education has grown (Koinzer, Nikolai and Waldow 2017). The proponents of school vouchers claim that heightened competition among private and public schools will reduce costs while simultaneously improving overall educational quality. Moreover, it has been argued that the introduction of market-like instruments such as vouchers will increase consumer choice, which is seen by many as a goal in its own right (Chubb and Moe 1989; Lundström and Wijkström 2012).

\subsection{A Note on the Necessary Political and Ideological Changes in the U.S.}

In 1980, Ronald Reagan was elected President of the United States based on a political ideology deeply influenced by Friedman's views on freedom, privatization, and market-based solutions. Reagan endorsed school choice and thus gave political legitimacy to an idea that, until then, had "remained far outside the mainstream" (Ravitch 2010: 121). The 1983 publication A Nation at Risk: The Imperative for Educational Reform is often cited as the beginning of the modern education reform push in the U.S. (NCEE 1983). The report, commissioned by the Reagan administration, concluded that the comparatively low quality of the American education system was problematic enough to be considered a national security risk. Even though A Nation at Risk says little to nothing about school vouchers or school choice, it sparked strong calls for new policy solutions to tackle the major social challenge of low academic achievement (Lieberman 1986, 1989; Chubb and Moe 1988, 1989).

The City of Milwaukee, the largest city in the state of Wisconsin, is located on the shores of Lake Michigan approximately $150 \mathrm{~km}$ north of Chicago. Known for its manufacturing industries and breweries and for being the birthplace of the Harley Davidson motorcycle company, Milwaukee also became the first city in the U.S. to implement a public funding for private school voucher program in 1990.

During the postwar era, the public school system in Milwaukee was strong and had broad public support. The city also had a thriving private school system with a significant number of vibrant Catholic and Lutheran schools. For example, in 1960, more than 50,000 students attended private schools in the city, which represented more than a third of all Milwaukee students (Witte 2000). However, in the 1970s, the once prosperous manufacturing industry started its historical decline that would ultimately make Milwaukee, and many other Midwestern cities, synonymous with the term "the rust belt". The economic downturn resulted in a sharp increase in unemployment, which hit the African American population especially 
hard. As noted by Miner (2013), by the late 1970s, the black unemployment rate in Milwaukee was nearly 20 percent, which was the highest in the country.

The economic troubles facing Milwaukee also started to affect the public school system. What had been a thriving system was now under severe stress. Here, we find the seed(s) leading to the creation of the voucher program at the core of our first case. As noted by Ford (2015: 91), some of the most important forces spurring a call for change were "the frustration over low academic achievement, the public perception of a school district unable to reform itself [and] the longsimmering perceived alienation of Milwaukee's African American community from a non-responsive MPS bureaucracy [...]”. Furthermore, education reform was considered very much needed, as a good education system was viewed as essential for creating and maintaining jobs in postindustrial Milwaukee. The above tensions and concerns brought strong calls for education reform to tackle the major social challenge of low academic achievement (Dougherty 2004). However, more unique to Milwaukee was the heavy emphasis placed on reforming public education through the use of new innovative structures as an alternative to traditional public education.

The reality that a market-based education reform could emerge in a city famous for its past socialist leadership is the result of a unique convergence of actors across the political spectrum, spearheaded by an increasingly vocal network of African American activists who had begun championing for black community schools in the city. A key leader of this movement, Howard Fuller, initially even wanted to see a separate school district controlled by the black community. As Miner (2013) notes, Fuller was convinced that such a district "could do a better job educating blacks than MPS, and he pointed to bureaucracy and the teachers' union as key impediments to reform. He also put forth an argument he would effectively resurrect in future controversies: 'there is no way that things could have been worse' than the current situation". The movement was able to find Allies within both the Democratic (e. g., Milwaukee mayor John Norquist) and Republican (e. g., Wisconsin governor Tommy Thompson) parties, and it was this coalition that ultimately enabled the voucher program to become a reality.

\subsection{The Milwaukee Parental Choice Program}

In June 1990, Wisconsin governor Thompson signed Wisconsin Assembly Bill 25 to create the first major private school voucher program, labeled The Milwaukee Parental Choice Program (hereafter MPCP). Its passage signified both a new era for public education and a first step toward legitimizing a once radical idea. In 
1990, the MPCP was perceived not as a significant threat to the existing public school system but rather an experimental pilot program. Thus, the MPCP was depicted as an initiative that provides state funding for low-income students to attend private schools located in the city of Milwaukee at no cost to them. Parents apply directly to the school they want their child to attend, and the school must enroll the child or, if they receive more applications than they have space, conduct a random lottery. Once enrolled, a student generates an annual payment to the school; however, a school cannot charge an MPCP pupil tuition. Any private school seeking to participate in the MPCP must meet a variety of regulatory requirements, including publicly releasing aggregate student test scores. However, independent schools still differ from the centralized Milwaukee Public School system in potentially meaningful ways. For example, schools accepting vouchers have considerable freedom from academic regulations, which allows them to be more innovative than the law permits for the Milwaukee Public Schools (Kava 2013).

In 1998, The Wisconsin State Supreme Court ruled that religious schools could participate in the MPCP (Witte 2000). The removal of the entry barrier for religious schools led to increased entrepreneurial activity and the formation of several new independent schools (Andersson and Ford 2017). Furthermore, the MPCP had grown popular among parents (Witte et al. 2008) and was heavily supported by Wisconsin Republican legislators, who strongly opposed any attempt to eliminate the MPCP. Today, more than 27,000 students use a voucher to attend over 110 private schools participating in the MPCP (Kava 2013), making it "in many respects the most important voucher program in the U.S.” (Epple, Romano, and Urquiola 2017: 448). In comparison, fewer than 80,000 students attend the Milwaukee Public Schools. The MPCP is such an established part of publi funding for education in Milwaukee that even ideological opponents of school vouchers acknowledge the program's permanent place in Milwaukee's education system (Borsuk 2014).

Interestingly, though school choice reform has expanded to other parts of the United States, there is no comparative case where a school voucher program has grown as fast or as broadly as in Milwaukee. The reasons, according to Ford (2015), are Milwaukee's unique case as the home of the Bradley Foundation (a main funder of school choice causes nationally), a strong African American leadership community explicitly advocating school choice, and widespread dissatisfaction with the traditional public school system. However, this confluence of policy factors has not taken place in other U.S. cities, in part because student outcomes in Milwaukee have not improved to any significant extent following the reforms (Ford 2015). 


\subsection{The Swedish Education System Before the Reform}

It was during the postwar era that the cornerstones of the Swedish social-democratic welfare state were laid (Esping-Andersen and Korpi 1987). The education reforms introduced in the 1940s-1970s were seen as a crucial part of the construction of the welfare state in Sweden (Blomqvist 2004; Lundahl 2005). During the 1940s, two state investigations paved the way for the comprehensive school system (enhetsskolan, later called grundskolan) that would remake the Swedish school system into one of the most centralized and state-controlled systems in the world (Lundahl 2005). Prior to this, there was a parallel-track school system (paralellskolesystemet) with various types of different schools. This system was largely class-based. Students from the upper and middle classes attended separate private schools that prepared them for higher education. At the beginning of the 1950s, the first pilot experiments for a new compulsory and comprehensive nineyear school system were conducted in an increasing number of areas of the country. The 1962 School Act stipulated that the compulsory and comprehensive school system was to be progressively introduced throughout the whole country. By 1969, the last two local authorities were reorganized and the reform was complete (Boucher 1981).

The new comprehensive school system clearly reflected social-democratic ideals of justice and integration (Lundahl 2005). Social-democratic school politician Britta Stenholm (1984) stated that regardless of their social and geographical origin, children should attend schools of equal and high standards and have equal opportunities for continuing to higher education. This would entail that all schools in the country be uniform in terms of educational content and organizational structure. Mixing children from different social backgrounds and achievement levels was further said to promote social integration and tolerance (Blomqvist 2004).

\subsection{The Swedish School Choice Policy Reform}

The early 1990s was in many ways a turbulent time for Sweden and its economy. Sweden experienced the worst labor-market crisis since the 1930s, and unemployment levels reached uniquely high levels (SOU 1993). Even when compared to the other Scandinavian countries, Sweden once stood out as the country where opposition to private alternatives within the school, healthcare, and social services sectors was most pronounced (Wolfe 1989). However, the general welfare policy in the country during the early 1990s experienced an economically and ideologically motivated turn toward a market orientation inspired by NPM practices. The aim 
was to make the welfare system more efficient by introducing business-inspired practices. This included decentralizing responsibility to municipalities, enabling market competition and opening up the welfare service market for private companies (Blomqvist 2004; Lewin 2014; Montin 1997).

During the late 1980s and early 1990s, the Swedish national school system went from being one of the most centralized and regulated school systems in the world to one that was highly decentralized. At the beginning of the 1980s, 0.2 percent of students were enrolled in non-public schools (Blomqvist and Rothstein 2000). The absolute majority of schools were run by the public sector, except for a small number of nonprofit schools based on a specific pedagogy, such as Waldorf, Montessori, and Reggio Emilia; a few schools operated by faith-based communities; and three national boarding schools. With few exceptions, students attended the public school in their catchment area. The social-democratic government in power in the late 1980s and early 1990s perceived a limited need for non-public schools (Blomqvist and Rothstein 2000). Regardless, under social-democratic rule, steps were taken toward a less homogenous and more diversified school system. In 1991, legislation was passed requiring municipalities to distribute resources to independent schools on the same basis as to municipal schools, that is, for instructional services provided. However, the legislation was designed so that resources were mainly distributed to independent nonprofit schools based on a specific pedagogy (Prop. 1990/91). These schools were by and large perceived as $a$ complement rather than a substitute to the population of rather homogenous public schools, which at the time was the general formula for nonprofit presence in the welfare system in Sweden (Lundström and Wijkström, 1997: 198ff). Moreover, that same year, a paragraph was added to the school legislation giving parents the right to choose between public schools for their children (SFS 1991:111).

In the fall of 1991, a center/right coalition gained power from the previous social-democratic government. The center/right coalition openly advocated a more liberal and market-oriented school system. Ideas concerning a school choice reform based on Milton Friedman's idea of vouchers had flourished in the youth section of the Moderate Party since the early 1970s. During the second half of the 1980s, the idea of school choice and vouchers became popular throughout the Moderate Party and in a new set of influential free-market think tanks such as Timbro (Wennström 2019). Although a relatively recent phenomena in Swedish the civil society and political landscape (Allern and Pollack 2016; Åberg, Einarsson, and Reuter 2019), some of the new think tanks came to influence education policy in Sweden. In 1991-1992, the center/right coalition carried out a school choice policy reform (Prop. 1991/92), for which Milton Friedman's voucher scheme was the main source of inspiration (Wennström 2019). This reform enabled students or their parents to freely choose between public schools and independent schools. It 
is important to point out that the notion of independent schools in Sweden simply indicates that the schools are run by an entity other than a municipality. This entity can be a private for-profit company, a charitable foundation, a nonprofit or voluntary association, a cooperative or a religious community (religiöst trossamfund). However, execution, regulation, financing, and control are mainly public activities. Independent schools have to follow the national curriculum and are forbidden to collect tuition fees.

When the center/right coalition allowed private providers to enter the newly created markets for key welfare services in the early 1990s, the coalition expected that civil society would step in and take over part of the burden from the state (Wijkström and Lundström 2002). The main policy goals for the school reform introduced have been identified as freedom of choice, higher-quality education, and greater cost-efficiency (Vlachos 2011; West 2017). First, freedom of choice was perceived as an ideological goal in its own right but also as a means for achieving other aims. Second, by opening up the school system for a wider range of providers and schools with various orientations and pedagogical profiles, schools would compete with one another and the overall quality of the school system would be improved. The Swedish Government, through School Minister Beatrice Ask, imagined that the new school system would open up for parent cooperatives, religious schools, and subject-focused schools and allow new opportunities for schools in rural areas threatened by closure to flourish with a new owner (Prop. 1991/92). Third, the reform aimed to create a school system that used resources more efficiently than the previous system.

In the new school system, a voucher for each student is issued by the government that can be redeemed at any school approved by the National Agency of Education (Skolverket). The reform initially required municipalities to distribute at least 85 percent of the average per-student cost in the municipal schools for each student enrolled in an approved independent school. The 15 percent discount reflected the fact that independent schools were not obliged to provide services such as school health care, home-language training, free meals, and transportation. When the Social Democrats returned to power in 1994, this percentage changed to 75 percent. However, in 1996, the grants were raised again because of a change in the legislation stating that independent schools should be able to act on the market under the same conditions as their public counterparts (prop. 1995/96: 200). Thus, independent schools now instead receive exactly (100 percent) the same average amount per student as public schools.

Under the current legislation, independent schools may adopt a religious orientation (konfessionell inriktning) as long as they follow the official national curriculum and adhere to the "goals and values" of the education system (SFS 2010:800). Schools with a religious orientation must adhere to the same guidelines 
regarding teaching as any other school in the country, either public or private. Thus, obligatory teaching hours must not be affected by the religious orientation of the school. The denominational activities taking place at religious schools are further strictly regulated. All religious activities, such as participating in worship services and teaching the religion of the school, must take place during voluntary extra-curricular time.

So far, we have described the historical and political background in the two settings for our study in an effort to highlight what preceded the reforms. In the following section, we present comparable data to examine what happened once the new reforms were in place.

\section{A Comparison of the Outcomes in the two Settings}

Superficially, the two voucher reforms seem to have resulted in similar outcomes in the two settings studied. In 2016, more than a quarter (26.4 percent) of all primary school students and almost one third (32.3 percent) of high school students in Milwaukee attended an independent school. In Sweden, the corresponding numbers for the same year (2016) were 15 percent of primary school students and a quarter (25.5 percent) of all high school students.

As seen in Figure 1, less than one percent of students in Milwaukee attended an independent school in the period 1992-1998, which is explained by the initial enrollment cap placed on the MPCP. In 1998, after voucher opponents had mounted a lengthy legal challenge, the Wisconsin Supreme Court not only upheld the legality of the MPCP but also opened up the program for religious schools to accept voucher students. Under the new rules, the number of voucher students started to rapidly expand and has been growing steadily. In Sweden, a gradual but rather modest growth in the share of students attending independent schools was experienced from the implementation of the reform until 2000. Since then, the growth has been more rapid, especially at the high school level. Over time, the development in our two cases seems to follow similar trajectories.

However, when examining what type of independent schools expanded or established themselves in the two contexts, stark differences become apparent. In Milwaukee in 2018, the official state report card included a total of 48 high schools and 225 primary schools, 12 and 81 of which were part of the MPCP, respectively. As seen in Figure 2, all independent schools in Milwaukee are run exclusively by Npos. This is true at both the primary school level and the high school level. Interestingly, over the history of the MPCP, there have only been two participating 


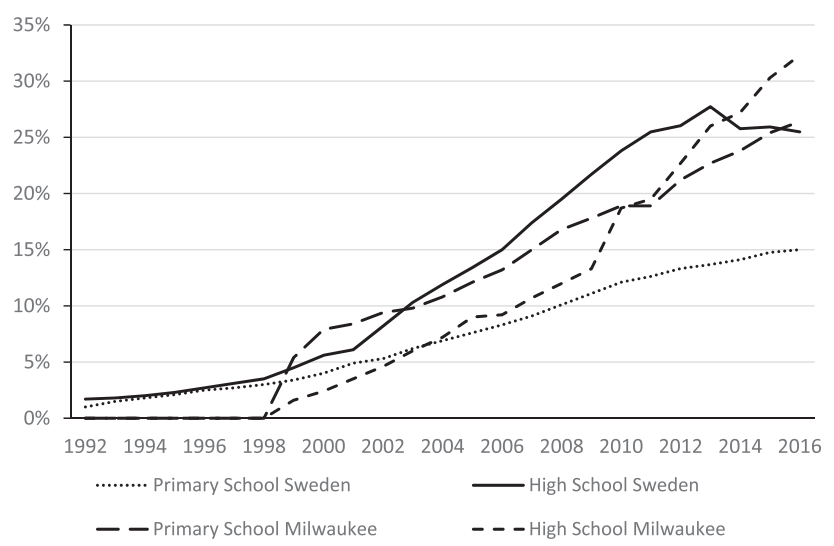

Figure 1: Share of students in independent schools, 1992-2016.

for-profit schools, and both of these schools were short-lived. No explicit barriers or legal constraints prohibit a school from being operated as a for-profit entity within the voucher system. In Sweden, there were 4,940 primary schools and 1,333 high schools in 2018. Out of these schools, 864 of the primary schools and 435 of the high schools were privately run. In contrast to Milwaukee, merely 38 percent (331 schools) of the independent primary schools and 12 percent ( 52 schools) of the independent high schools were run by Npos. The remaining 62 percent of the independent primary schools and 88 percent of the independent high schools were run by for-profit corporations.

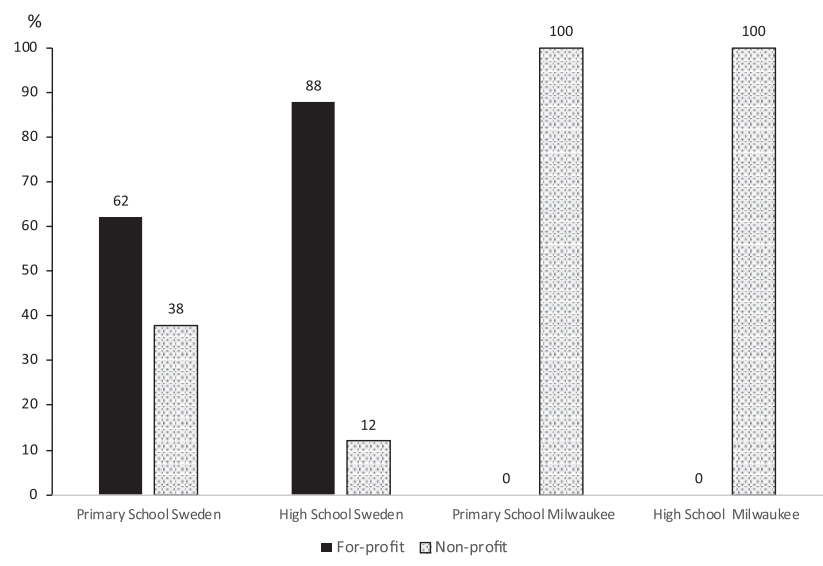

Figure 2: For-profit versus nonprofit schools in 2018. 
The fact that an entirely new breed of for-profit enterprises would come to dominate the independent school sector in Sweden was not obvious during the very first decade after the reform (Figure 3). Two years after the reform was implemented, a mere 0.1 percent of school employees worked in for-profit schools, and employment in non-government schools - for-profit as well as nonprofit constituted only 1.2 percent of the total. During the remaining years of the 1990s, the shares of employees working in nonprofit and for-profit schools both gradually grew; nonetheless, in 2000, there were still twice as many employees working in nonprofit schools as in for-profit schools (Trydegård 2001). However, after 2000, growth in the number of for-profit schools accelerated dramatically. This indicates that it took close to a decade for private economic interests to conceive of primary and secondary education as a promising business opportunity.

Another stark difference between the two cases lies in the sheer percentage of independent schools operated by religious communities or faith-based welfare institutions (Figure 4). In Milwaukee, the absolute majority of independent schools are religious nonprofit schools. As noted earlier, private schools in the U.S. have predominately been schools with an explicit religious affiliation. Religious schools are thus nothing new in the American context. However, the MPCP granted access to funding that had previously been unattainable for this group of schools, leading many existing nonprofit religious schools in Milwaukee to join the MPCP. In Sweden, in comparison, there were 66 religious schools at the primary school level and only five religious schools at the high school level. This represented a mere five percent of the total number of independent schools.

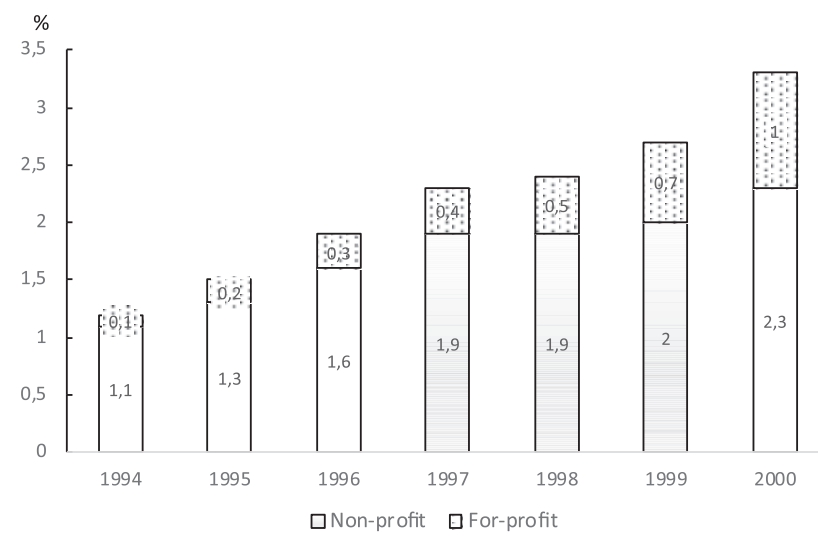

Figure 3: Share of employees in nonprofit versus for-profit schools in Sweden, in percentage 1994-2000 (adjusted from Trydegård 2001). 


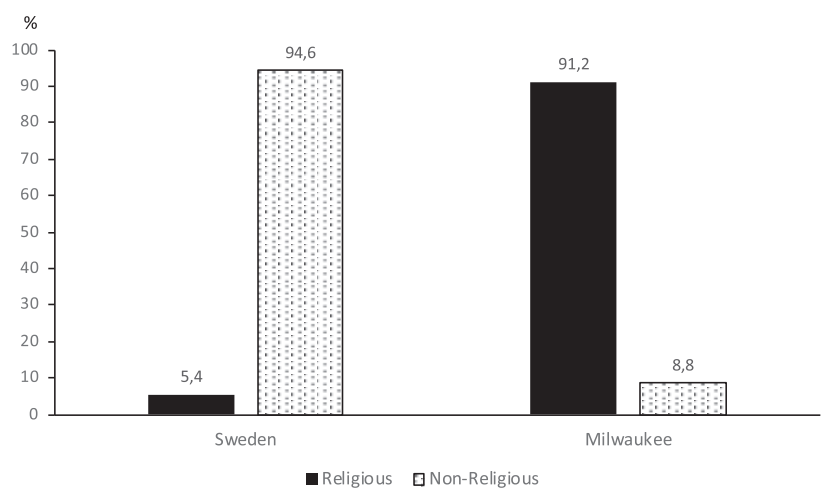

Figure 4: Religious versus non-religious schools in 2018.

\section{An Analytical Frame for our Interpretation of the Outcomes}

Despite many similarities in terms of theoretical inspiration and legislative design observed as this particular NPM trend - a school-voucher system - travels across the globe (Sahlin-Andersson 2002), the two different school systems in our analysis ended up being strikingly different even if they appeared similar at first glance. This is particularly true when considering the type of new schools that did enter and establish themselves in the new systems. It is interesting to note how the early global or transnational architects of the system for school vouchers, as well as the local politicians in each of the two systems implementing the school choice reform in the early 1990s, envisioned a highly diversified and pluralistic school market where students and parents could choose freely among schools with distinct qualitative differences in pedagogical profiles and orientations (Friedman and Friedman 1980; Trydegård 2001). However, instead of high degrees of diversity, both studied systems are characterized by uniformity in the first decades following the reforms; nonetheless, this uniformity differs between the two cases compared, which is important (see also Lundström and Wijkström 2012).

In a review of Salamon and Anheier's social origins article from 1998, Ragin (1998) argues that in-depth comparative and historical research might be the only viable way to study the nonprofit sector across regimes. Ragin argues that the historical development of Npos is likely to be not only country specific but also subsector specific, and "in the end, comparative analysis should be grounded in in-depth knowledge of the historical development of specific subsectors across countries" (Ragin 1998: 362). In this article, we follow this 
approach and apply a more holistic analysis of differences in the country-specific "civil society regime" between the two systems. We analyze how these particular civil society regimes have impacted the development of the field of education in the two settings.

Sweden ended up with a school system where the group of new entrants was dominated by for-profit enterprises running schools that seemed to mimic the already existing population of public schools, whereas the voucher system introduced in Milwaukee led to a situation with new nonprofit schools predominantly run by faith-based communities and largely reliant on the new school voucher revenues. How can these striking differences in outcomes between the two systems be understood and explained?

In this section, we attempt to answer this question by focusing on three overarching factors and conditions at the national civil society regime level with an impact on this matter: (i) the differing attitudes toward the role of the state and the role of religion in the U.S. and Sweden; (ii) the substantial differences in the type and magnitude of pro-nonprofit intermediary actors, umbrella organizations and other - primarily philanthropic - supportive structures focusing on educational issues in the two contexts; ; and (iii) the contrasts in the pre-existing population of education providers when the reforms were implemented.

\subsection{Different Attitudes Toward the Roles of Religion and the State in the U.S. and Sweden}

The U.S. remains one of the most religious countries among the world's more developed nations. A vast majority of American adults say they believe in God and consider religion to be an important aspect of their lives (O’Neill 2002). In Milwaukee specifically, religious traditions created a strong, resilient, and highly established network of nonprofit schools. By contrast, Sweden is often said to be one of the most secular countries in the world. Merely five percent of the population attends religious services weekly, and two-thirds of the population state that they have not attended a religious service in the last year (Willander 2019). Furthermore, Sweden has historically been religiously homogenous, and despite low levels of religiosity, membership rates in the Church of Sweden have been high. In the mid-1970s, some 95 percent of the Swedish population formally belonged to the Church of Sweden, and still in the late 1990s, as many as 85 percent of the population was members (Svenska kyrkan 2018).

The differing degrees of religiosity are also manifested in the centrality and the role of religious and faith-based organizations in the two contexts. Today, there are an estimated 380,000 religious congregations in the U.S. (Brauer 2017), and as 
commented by O'Neill (2002: 62), religion is something that goes far beyond congregational worship, which is why "[r]eligion directly touches far more people than any other part of the U.S. nonprofit sector”. Even as secular tendencies have often seemed to overshadow faith traditions, Hammack and Anheier (2013: 126127) argue that religion has remained a central focus for many U.S. philanthropic foundations: "Moving beyond their earlier focus on 'mainstream' Protestant denominations and reform Judaism, foundations increasingly support evangelical Protestantism, Catholicism, and Orthodox Judaism”.

"Faith-based organizations in the United States are broadly of two kinds: those that engage in service activities and those that focus on community organizing" (Wuthnow 2005: 613). Specifically, many religious institutions, for example faithbased welfare providers, are deeply embedded in the U.S. social fabric and channel significant volunteer efforts and financial resources to activities reaching far beyond religious worship. Hodgkinson and Weitzman (1993) surveyed more than 700 religious congregations and reported that over 90 percent of them were involved in human service activities, 90 percent in health-related activities, and 62 percent in advocacy activities; additionally, more than half (53 percent) performed some kind of educational activities. Moreover, in 2013, 69 percent of private schools in the U.S., enrolling 79 percent of private school students, had a religious orientation or purpose (Broughman and Swaim 2016).

Religious and faith-based institutions are not only key providers of welfare in the U.S., but are also often viewed in a more favorable light compared to government-provided welfare institutions. As noted by Grønbjerg (2002: 218), the political economy of the U.S. is guided and driven by a very positive view of the free market but also by "a deeply ingrained suspicion of virtually all public programs and authorities, which are viewed as inefficient, subject to favoritism, and antagonistic to the much-preferred system of private initiative, unless carefully controlled and monitored”. Religious organizations, by contrast, are private organizations that enjoy a privileged position in American law and have taken on or been given - a very different and key role in this political economy (Salamon 1992). For example, O’Neill (2002) observes how when Americans are asked about the degree of confidence they have in various social institutions; religion is consistently ranked at or near the top, far above any level of government or the corporate sector. One of the most recent consequences of the central role of religion in the welfare system in the U.S. is the initiative initially taken by the Bush administration in 2001 but upheld by a line of American presidents to establish a special office in the White House to promote and expand the activities by faithbased actors (see also Wuthnow 2005).

In Sweden, the Evangelical Lutheran Church and its parishes had a prominent role in both the provision and governance of welfare services, including education, 
in the period before the formation of the Swedish welfare state in the early 20th century. In the early stages of the formation of the Swedish welfare state, the responsibility for key welfare services - such as education, health care, and social services - were transferred from the Church to the state and the public sector. Moreover, as part of this development, the Church of Sweden was integrated into the framework of the welfare model in the role of a "folk Church" (Edgardh and Pettersson 2010). A clear division of labor was created between the state and the Church, where the Church was given special responsibility for providing spiritual and religious services (e. g., religious rites) and complementary social services (e. g., counseling) (Bäckström 2014). Consequently, the historical specificities of the state-church relationship in Sweden resulted in the establishment of a welfare state model that did not incorporate churches or religious organizations as providers of key welfare services (Göçman 2013). In 2000, the disestablishment of the Church of Sweden as a formal part of the state resulted in a liberalization of the regulations and legal framework that had governed state-church relations for many centuries since the Reformation.

Since the Church of Sweden was formally separated from the state in 2000 and came to legally hold a more similar position vis-á-vis the state as other institutions of faith in the country, the expectations of its role as a direct provider of welfare services and as a defender of values of solidarity and care have started to change. However, even in parts of the Church of Sweden that are more positive toward Church-based welfare provision, this welfare still seldom reaches beyond what could perhaps be understood as "welfare light", leaving major welfare institutionssuch as schools, hospitals, and institutions of higher education to be operated by the public sector (Mann, Einarsson, and Wijkström 2014). Even if the combination of a partly new situation for independent welfare providers in the Swedish welfare system, and a Church of Sweden that no longer is a state church, might open for a new and more pronounced role for the Church in the actual provision of welfare (Wijkström 2014), the current situation points to a very careful - perhaps even hesitant - Church in this respect (Bäckström 2014b).

Moreover, even if religious organizations are emerging as more autonomous social agents, the traditional division of labor between the state and the church regarding welfare provision is still reflected in the public opinion on the matter. A study by Bäckström and Davie (2010) shows that the majority of people in the Nordic countries (including Sweden) believe that the state should have the primary responsibility for the provision of welfare services, while nonprofit organizations, in general, may adopt a more complementary role (see also Lundström and Wijkström 1997: 198-199). In particular, the research conducted by Bäckström and Davie (2010) shows a widespread public distrust in Sweden toward religious or faith-based actors providing core welfare services. The long-term and widespread 
public distrust in Sweden toward welfare producing religious or faith-based organizations seems to be particularly acute regarding actors operating in the education system (Hollmer and Bäckström 2014). The activities of welfare provision are perceived as part of a conceptual idea of the secular state taking care of its citizens from the cradle to the grave, and thus, religious influence in welfare provision is by many perceived as a threat to secular homogeneity.

In short, as a consequence of the fact that the religious landscapes look very different in Sweden and the U.S., the scope and acceptance of faith-based providers of welfare, including education, are substantially wider in the U.S. than in Sweden.

\subsection{The Importance of Resourceful and Powerful Nonprofit Intermediaries}

As depicted in the historical background section of this article, the Swedish reform can be described as primarily ideologically inspired and characterized by political top-down decision making. Freedom of choice was perceived as a goal in its own right and as a main driver for the reform implementation. The reform in Milwaukee,

which certainly contained strong ideological and political elements, was more of a bottom-up approach as it was propelled by a grassroots movement that was able to span and connect political and ideological boundaries. How the reforms developed and were implemented illuminates a distinct difference between Sweden and Milwaukee. In Sweden, the reform was predominantly an internal affair with relativity few actors involved. By contrast, the reform in Milwaukee was, and continues to be, deeply embedded in a broad and deep infrastructure composed of numerous stakeholders. As a consequence, the type of direct and indirect support coming from powerful external stakeholders, including advocacy organizations and philanthropic institutions, was and remains distinctly different in the two contexts.

As mentioned, Milwaukee also had an established tradition of private faithbased education, meaning that the infrastructure for voucher programs of some kind was in place from the beginning. Witte (2000: 161) comments: "[t]he one more or less constant in the voucher movement is the Roman Catholic Church”. Indeed, Milwaukee's Catholic Archdiocese was a major supporter of the establishment of the MPCP, and today, almost all Milwaukee Catholic schools participate in the MPCP. Other organizations, including the Wisconsin Religious and Independent Schools Association (WRISA) and the Wisconsin Lutheran Synod, work closely with school choice advocates to support and expand the MPCP. However, these organizations have been less influential than the Catholic Archdiocese, and they 
are significantly smaller. Milwaukee has historically been the stronghold of the Catholic community in the State of Wisconsin, and it is worth remembering that there were several Catholic private schools in Milwaukee long before the voucher program was implemented.

However, the school choice movement has not only been given political support by various advocacy groups. It has also been backed by important sources of philanthropic support. One of the most prominent think tanks and financial supporters of Milwaukee's school choice movement is the Lynde and Harry Bradley Foundation. Though the foundation began in 1942, it started taking a greater interest in school choice reforms during the 1980s. The Bradley Foundation funded scholarly works across the country, including Chubb and Moe's (1989) seminal work on market-based school reform, which helped create a powerful conceptual foundation for voucher systems. In Wisconsin, the foundation further funded the Wisconsin Policy Research Institute (WPRI), a think tank that was part of creating the intellectual basis and foundation for the MPCP in Milwaukee. The WPRI also produced many studies pointing out flaws in the traditional public school system and offering specifics as to how a school voucher program could operate in Milwaukee.

The Bradley Foundation also supported Partners Advancing Values in Education (PAVE), a nonprofit group with close ties to the Catholic Church. Early on, PAVE advocated strongly for the creation of a school-voucher program as well as for the inclusion of religious schools in the program once created. PAVE even provided scholarships to students attending religious schools while the question of religious school participation was litigated. The Milwaukee Metropolitan Association of Commerce (MMAC), a Milwaukee-based business membership organization, was also funded by the Bradley Foundation. MMAC chose school reform as its top issue, viewing school reform as a means to attract new businesses to Milwaukee. MMAC also employed Susan Mitchell as its consultant. Mitchell would go on to be the president of the American Education Reform Council (AERC) and later School Choice Wisconsin (SCW). AERC eventually became a national advocacy group, while SCW is still the most prominent and effective pro-voucher lobbying group in Wisconsin.

The organizations advocating for school choice in Milwaukee remained connected through a dense web of funders that included both the Bradley Foundation and the Walton Foundation (a foundation created by the founders of the huge retail corporation Walmart). Both of these large national philanthropic groups have provided funding to multiple organizations, including direct support to individual private schools, and a revolving door of parent advocacy groups that would often change their name and focus. Undeniably, these agents helped enable the successful passage of the voucher policy in Milwaukee. 
More importantly, today, many of these organizations are still active and have transformed into commanding intermediaries. PAVE has transitioned from playing an advocacy role to being a support organization for individual independent schools. SCW is still the most powerful lobbying group for school choice in Wisconsin, and played a key role as the voucher program expanded statewide in 2013. The MMAC is still active in voucher policy but also focuses on strengthening the charter school sector. The Black Alliance for Educational Options, which received funding from Bradley and Walton, recently closed its doors. WPRI is now known as the Badger Institute but still produced white papers in favor of school choice policy. Though the agents have changed over time, the funders, including Bradley and Walton, remain involved with most Milwaukee-based school choice reform advocacy and support organizations.

In the late 1980s and beginning of the 1990s, Sweden had nothing close to the trans-partisan advocacy groups or web of funders successfully lobbying for the Milwaukee school voucher program. Not even on the more general level of support for volunteer programs and philanthropic initiatives can we notice any Swedish national actor of significance before the mid-1990s (Wijkström 2017). The only organization actively lobbying for school choice and school vouchers before the reform was Timbro, a Swedish right-wing market-friendly think tank with close connections to the conservative Moderate Party and the business and trade sector (Wennström 2019). Timbro, as one of the most influential conservative and promarket think tanks at the time, also translated Milton and Rose Friedman's Right to Choose into Swedish in 1980.

Due to the marginal presence of independent schools in Sweden before the school choice reform, no designated umbrella or interest organization existed to promote the interest of these schools until after the reform was already in place. In 1995, the Swedish Association for Independent Schools (Friskolornas riksförbund) started to represent both for-profit and nonprofit schools. The organization was fashioned in accordance with the Swedish model for organizational membership-based interest organizations. Today, the organization has approximately 500 individual schools as members. It was not until 2013 that an organization was started to promote the interest of solely nonprofit schools. Today, that organization has 45 individual member schools and openly advocates against for-profit schools operating in the Swedish context. The lack of such an organizational structure in the Swedish case can be traced back to the differences in the composition and configuration of civil society in the two contexts, not the least the active expansion of the public sector and the parallel downgrading of charity and philanthropy within welfare taking place during the foundational stages of the building of the social-democratic welfare state in Sweden during the 1900s (Wijkström and Einarsson 2018). Moreover, to understand this void, it is 
important to distinguish between American-style advocacy organizations and philanthropic foundations and the interest organizations and popular mass movements common in the Swedish context.

The traditional and most acknowledged role of civil society organizations in the Swedish context is to serve as vehicles through which individuals can advance their political, social, and even recreational interests (Lundström and Wijkström 1997; Salamon and Anheier 1998; Trägårdh 2010). These interests are commonly pursued through large-scale membership associations, or "the popular movements" (folkrörelserna), which differ widely from the 19th century tradition of philanthropic institutions and benevolent societies, as summarized by Wijkström (2016). The Scandinavian organizational model and governance structure have - primarily as a result of a concomitant development of an extensive welfare state and an expanding popular-movement regime in civil society - historically been characterized by both vertical and horizontal cooperation between the state and the nonprofit sector (Selle et al. 2018: 41).

Democratically organized popular movement organizations in Scandinavia have traditionally contributed to a strong integration between local and national governance levels as well as cooperation between actors at the same level. These features of the Swedish civil-society regime have enhanced the ability of civil society actors to influence policy and solve collective problems (Lundström and Svedberg 2003). Swedish popular movement organizations and interest organizations are founded on well-defined ideologies and primarily promote the interests of their members, although other organizations have also assumed this basic form of large-scale member organizations, such as the Red Cross or Save the Children. Of course, in Sweden, there also exist other types of organizations, notably traditional societies (sällskapen) and classical philanthropic institutions, but their contribution to contemporary Swedish civil society is marginal. Although, from a low aggregate level, there has been a marked increase in the interest in and prominence of these organizations in recent decades (Wijkström 2017; Wijkström and Einarsson 2018).

In summary, the historical existence of a broad range of external nonprofit and faith-based stakeholders has deeply shaped the Milwaukee voucher school system. In the case of Sweden, by contrast, the void of advocacy groups and philanthropic foundations largely conceded the newly opened playing field to forprofit providers. The fact that the provision of education was almost exclusively a public responsibility before the implementation of the school voucher reform in Sweden explains the lack of influential membership organizations lobbying on behalf of nonprofit and faith-based schools. 


\section{Conclusion}

We have examined the processes surrounding the emergence of a new educational landscape in two different institutional settings from the launch of early pioneering school choice policy initiatives to the current organizational configuration and mix of different educational providers. Considering the global rise of the NPM approach in public policy, in combination with the isomorphic tendencies observed in national education systems, a plausible assumption regarding the enactment of school voucher systems in both Sweden and Milwaukee is that they would generate and convert toward a similar educational geography. However, as illuminated in this article, the school choice reforms have resulted in two profoundly different institutional arrangements and organizational outcomes. We show that the civil society regime and the overall nonprofit context are of considerable importance for the outcome when school reforms aimed at opening up for institutional diversity are introduced. In particular, it can have a powerful and long-lasting effect on the type of entrant we notice. We argue that the resulting composition of providers is directly related to three specific dimensions of the relevant civil society regime.

The first dimension concerns the role of religious organizations in the respective welfare systems. Faith-based nonprofit providers are natural actors in the U.S. welfare system, not the least when it comes to education. In contrast, the historically very close state/Church relationship and the division of labor ${ }^{1}$ between the Church and the rest of the public sector explain the weak position of schools operated by religious communities in Sweden.

Second, the presence of intermediary organizations, such as advocacy and lobby organizations and philanthropic funders, is critical to reform outcomes. In Milwaukee, the reform started as a grassroots movement that engaged a broad spectrum of different organizations, including think tanks and policy institutions, pushing for change. The few existing nonprofit welfare providers existing in Sweden in the early 1990s did not have the necessary intermediary infrastructure of interest or lobby organizations to push or defend their case, as they did in Milwaukee. Moreover, our data uncover the importance of a set of strong philanthropic actors in Milwaukee with both the ambitions and the financial muscle to

\footnotetext{
1 Sweden's religious landscape was dominated by a Lutheran state Church from the late 1500s up to 2000, when the Church of Sweden was formally separated from the state. From the construction of the social-democratic welfare state and onwards, there was a rather clear division of labor between the "secular" (public sector) and the "Church" municipalities, where the regulation, funding, and provision of welfare - including education - were the responsibility of the public sector and the "secular" municipalities.
} 
back the nonprofit sector. Thus, voucher schools in Milwaukee had the possibility of combining revenue from public funding with access to the multi-billion-dollar philanthropic sector, where religion and education represent the two top causes for philanthropic donations. In contrast, the Swedish educational landscape does not contain any strong philanthropic actors (Braunerhjelm and Skogh 2004; Wijkström and Einarsson 2018).

Finally, the composition of existing population of providers will, due to path dependency, impact what kind of actors expand or establish themselves in the new system. When the voucher reform was implemented in Milwaukee, a pre-existing population of nonprofit educational providers was already present and ready to take action once the voucher policy window opened. Thus, the new independent schools emerged in the well-established tracks carved out by decades of religious nonprofit schools embedded in a particular civil society regime (see also Silverman 2012, on charter schools in New York). Sweden, on the other hand, had few privately operated schools before the reform. This nonprofit void was instead filled by an aggressive population of new for-profit providers. A key takeaway from the above analysis is that there was never a strong population of Swedish faith-based providers and there was very weak institutional support for Npos in general when the school reform was introduced in the Swedish context. The opposite could be said of the Milwaukee setting. So, how should policymakers interpret these findings?

\section{Discussion and Policy Implications}

\subsection{Global Themes - Local Variations - Existing Civil Society Regime}

In many countries, the changing role and situation for private providers - forprofit, as well as nonprofit - contribute to substantially transformed welfare systems (for Sweden, see Blomqvist and Rothstein 2000; Wijkström and Lundström 2002). Some of these changes have been lubricated by the explicit introduction or change of government policies aimed at altering the relations specifically between the public sector (government) and civil society (e. g., Johansson and Johansson 2012; Reuter, Wijkström, and von Essen 2012). Other changes have been shown to run in parallel with a transformed role or renewed interest in society for volunteering, foundations or other types of philanthropic practices, sometimes labeled "neo-philanthropy" (Villadsen 2007; Wijkström and Einarsson 2018). These changes run in parallel to the previously discussed NPM solutions that for example, opened up the education system for school vouchers and other market practices. 
A superficial tendency toward isomorphism can be noted at the transnational or global level in terms of new welfare policy initiatives. However, even if these changes globally seem to be running in the same direction, both the differences in the existing civil society regime in our two settings and variations in the relationship between the government and the nonprofit sector (cf. Sjöstrand 2018) are of utmost importance. Thus, even if a kind of isomorphism is evident on the global or transnational surface in regard to the travel and adaptation of worldwide policy and management models - which, in the words of Drori, Höllerer, and Walgenbach (2013), would be described as "global themes" - path dependency and translation to local conditions at the local (national) level, or the "local variation", still have a strong influence on the outcome (see also Czarniawska-Joerges and Sevón 2005).

The kind of institutional inertia this condition represents cannot be stressed enough and must be taken into consideration by policymakers and welfare providers alike. Hence, as policymakers consider the role of the public versus the market, they must also consider how existing civil society regimes might impact policy reforms. Our two cases illuminate the importance of not equating two very different contexts that pose substantially different possibilities and problems for educational entrepreneurs: creating schools within an institutionalized civil society context versus striking out into uncharted waters. To better understand and predict the impact of educational reform proposals, policymakers are therefore well advised to identify, and when necessary distinguish between, different civil society regimes.

We argue that as policy reforms are implemented and give rise to new or expanding organizations, existing civil society institutions both constrain and imprint on these organizations as they surface and evolve. While studies have previously examined the differences in civil society regimes and the social origins of civil society and subsequent differences in more specific areas, such as philanthropy across countries, these differences have seldom been explicitly linked to the life-cycle or policy ramifications of specific industries or fields, such as education. Barbetta et al. (2018) find similar results for Italy, where they compare the entry of new nonprofit actors across the North-South divide: "Our data show that Southern citizens are at least as willing and able to create new Npos as their Northern counterparts. What really makes the difference is the capacity of these new organizations to survive and thrive over time. Therefore, the environment (and its impact on Npos) appears to play a relevant role in determining the success of the sector" (Barbetta et al. 2018: 10).

Thus, policymakers seeking to advance school choice policy must not only consider the actions of existing schools and individual school entrepreneurs but also extend their analysis to include the wider institutional landscape or entrepreneurial ecosystem in which independent schools are expected to flourish. 
Entrepreneurial ecosystems have been described as "combinations of social, political, economic, and cultural elements within a region that support the development and growth of innovative startups and encourage nascent entrepreneurs and other actors to take the risks of starting, funding, and otherwise assisting highrisk ventures" (Spigel 2017: 50). As shown in our study, it is crucial to understand the prevailing civil society and its dense - or non-existing - intermediary structures to make sense of this institutional landscape and the tendencies toward greater degrees of isomorphism or heterogeneity.

The Sweden and Milwaukee cases further clearly signal that school choice policy can be a potent instrument for impacting the supply of educational services by incentivizing the creation of new schools. In both contexts, educational entrepreneurs have seized the opportunity to launch new educational entities. This is in line with arguments made by some scholars (e. g., Hess 2008) that a core aspect of school choice policy is to question the ability of existing schools and school districts to reinvent the system from within and instead to create the type of disruption necessary to improve education by stimulating new entry. This perspective first and foremost distinguishes between schools that are replicators and schools that are innovators, pioneering practices without precedent.

\subsection{Implications for the Next Generation of Nonprofit and Civil Society Scholarship}

Finally, our research also has some implications for nonprofit scholars. In particular, we want to encourage the continuation of comparative and longitudinal investigations of nonprofit-relevant policy fields. Today, we have a pretty good picture of the major similarities and differences between national civil society regimes thanks to comparative research projects such as the Johns Hopkins study of nonprofit sectors, but what we lack is a more detailed analysis of how particular fields or subsectors, like education, operate under the conditions set by the specific civil society regime (Enjolras 2009). To push research, we thus need to conduct multi-layered analysis of transformative processes, as argued by, for example, Sahlin-Andersson (2002). For example, as nonprofit and civil society scholars continue to study how policy shapes or creates new opportunities for nonprofit and voluntary action, they would also benefit from identifying patterns of connectivity between the nonprofit actors who founded new ventures and the embeddedness in their respective communities. Also the role and impact of think tanks, policy institutes and other new vehicles for advocacy in shaping the relevant domestic or global landscape (Djelic 2017) is currently understudied in many fields of the nonprofit sector. Moreover, the importance of paying attention to the differing 
relationships between established religion and the state in different welfare state contexts cannot be stressed enough. Researchers need to pay attention to how the presence or absence of religion in key areas of welfare delivery helps to shape public policy and service provision. The investigation of these ideas will likely require that we expand the disciplinary reach and include additional theoretical approaches for understanding the genesis of contexts that give meaning to new nonprofit behaviors.

\section{References}

Åberg, P., S. Einarsson, and M. Reuter. 2019. "Think Tanks: New Organizational Actors in a Changing Swedish Civil Society." VOLUNTAS: International Journal of Voluntary and Nonprofit Organizations, Published online: 1-15. https://doi.org/10.1007/s11266-019-00174-9.

Allern, S., and E. Pollack. 2016. "Swedish Advocacy Think Tanks as News Sources and AgendaSetters.” Politik 1 (19): 61-76. https://doi.org/10.7146/politik.v19i1.27395.

Andersson, F. O., and M. Ford. 2017. "Entry Barriers and Nonprofit Founding Rates: An Examination of the Milwaukee Voucher School Population.” Nonprofit Policy Forum 8 (1): 71-90. https:// doi.org/10.1515/npf-2016-0021.

Anheier, H. K., and L. M. Salamon. 2006. "The Nonprofit Sector in Comparative Perspective.” In The Nonprofit Sector: A Research Handbook, edited by W. W. Powell, and R. Steinberg, 89-115, 2nd ed. New Haven, CT: Yale University Press.

Anheier, H. K. 2010. "Social Origin Theory." In International Encyclopedia of Civil Society, edited by H. K., Anheier, and S., Toepler, New York, NY: Springer.

Archambault, E., E. Priller, and A. Zimmer. 2014. "European Civil Societies Compared: Typically German-Typically French?.” Voluntas 25 (2): 514-37. https://doi.org/10.1007/s11266-0139349-6.

Bäckström, A., G. Davie, N. Edgardh, and P. Pettersson, eds. 2010. Welfare and Religion in the 21th Century Europe: Volume 1. Configuring the Connections. Farnham: Ashgate.

Bäckström, A. 2014a. "Religion in the Nordic Countries: Between Private And Public." Journal of Contemporary Religion 29 (1): 61-74. https://doi.org/10.1080/13537903.2014.864804.

Bäckström, A., eds. 2014b. Välfärdsinsatser på religiös grund. Skellefteå: Artos och Norma Förlag.

Barbetta, G. P., P. Canino, S. Cima, and F. Verrachia. 2018. "Entry and Exit of Nonprofit Organizations. National, Sectorial and Geographic Trends With Italian Census Data.” Nonprofit Policy Forum 9 (2): 1-12. https://doi.org/10.1515/npf-2017-0036.

Blomqvist, P., and B. Rothstein. 2000. Välfärdsstatens nya ansikte. Stockholm: Agora.

Blomqvist, P., and U. Winblad. 2019. "Why no Nonprofits? State, Market and the Strive for Universalism in Swedish Elder Care." Nonprofit and Voluntary Sector Quarterly 48 (3): 1-19. https://doi.org/10.1177/0899764018819870.

Blomqvist, P. 2004. "The Choice Revolution: Privatization of Swedish Welfare Services in the 1990s." Social Policy \& Administration 38 (2): 139-55. https://doi.org/10.1111/j.1467-9515. 2004.00382.x. 
Borsuk, A. 2014. “For Better or Worse, Walton Family Foundation Plays Role in Milwaukee." The Milwaukee Journal Sentinel. http://archive.jsonline.com/news/education/for-better-orworse-walton-family-foundation-plays-role-in-milwaukee-b99180157z1-239756931.

Boucher, L. 1981. Tradition and Change in Swedish Education. Oxford: Pergamon Press.

Brauer, S. G. 2017. "How Many Congregations are there? Updating a Survey-Based Estimate." Journal for the Scientific Study of Religion 56 (2): 438-48. https://doi.org/10.1111/jssr. 12330.

Braunerhjelm, P., and G. Skogh. 2004. Sista fracken inga fickor har: filantropi och ekonomisk tillväxt. Stockholm: SNS förlag.

Bromley, P., and J. Meyer. 2015. “"They are All Organizations”: The Cultural Roots of Blurring Between the Nonprofit, Business, and Government Sectors." Administration and Society 49 (7): 939-66. https://doi.org/10.1177/0095399714548268.

Broughman, S. P., and N. L. Swaim. 2016. Characteristics of Private Schools in the United States: Results From the 2013-14 Private School Universe Survey (NCES 2016-243), Washington, DC: National Center for Education Statistics, Institute of Education Sciences, U.S. Department of Education.

Carnoy, M. 1998. "National Voucher Plans in Chile and Sweden: Did Privatization Reforms Make for Better Education?.” Comparative Education Review 42 (3): 309-37. https://doi.org/10.1086/ 447510.

Chubb, J., and T. Moe. 1988. "Politics, Markets, and the Organization of Schools." The American Political Science Review 82 (4): 1066-87. https://doi.org/10.1111/j.1467-9752.1994. tb00332.x.

Chubb, J., and T. Moe. 1989. Educational Choice: Answers to the Most Frequently Asked Questions About Mediocrity in American Education and What Can be Done About It. Hartland, WI: Wisconsin Policy Research Institute.

Czarniawska-Joerges, B., and G. Sevón, eds. 2005. Global Ideas. How Ideas, Objects and Practices Travel in the Global Economy. Stockholm: Liber.

Djelic, M.-L. 2017. "Building an Architecture for Political Influence: Atlas and the Transnational Institutionalization of the Neoliberal Think Tank." In Power, Policy and Profit: Corporate Engagement in Politics and Governance, edited by Garsten, C., and A. Sörbom. Cheltenham: Edward Elgar.

Dougherty, J. 2004. More Than One Struggle: The Evolution of Black School Reform in Milwaukee. Chapel Hill, NC: The University of North Carolina Press.

Dronkers, J., and P. Robert. 2008. "Differences in Scholastic Achievement of Public, Private Government-Dependent, and Private Independent Schools. A Cross-National Analysis.” Educational Policy 22 (4): 541-77. https://doi.org/10.1177/0895904807307065.

Drori, G., M. Höllerer, and P. Walgenbach. 2013. Global Themes and Local Variations in Organization and Management. Abington-on-Thames: Taylor \& Francis.

Edgardh, N., and P. Pettersson. 2010. "The Church of Sweden: A Church for All Especially the Most Vulnerable.” In Welfare and Religion in $21^{\text {st }}$ Century Europe: Volume 1, edited by A. Bäckström, and G. Davies. Farnham: Ashgate Publishing Limited.

Emmenegger, P., J. Kvist, P. Marx, and K. Petersen. 2015. “Three Worlds Of Welfare Capitalism: The Making of a Classic.” Journal of European Social Policy 25 (1): 3-13. https://doi.org/10.1177/ 0958928714556966.

Enjolras, B. 2009. "Between Market and Civic Governance Regimes: Civicness in the Governance of Social Services In Europe." VOLUNTAS: International Journal of Voluntary and Nonprofit Organizations 20 (3): 274-90. https://doi.org/10.1007/s11266-009-9091-2. 
Epple, D., R. E. Romano, and M. Urquiola. 2017. "School Vouchers: A Survey of the Economics Literature.” Journal of Economic Literature 55 (2): 441-92. https://doi.org/10.1257/jel. 20150679.

Esping-Andersen, G. 1990. The Three Worlds of Welfare Capitalism. Princeton, NJ: Princeton University Press.

Esping-Andersen, G., ed. 1996. Welfare States in Transition. Social Security in the New Global Economy. London: Sage.

Esping-Andersen, G. 1999. Social Foundations of Postindustrial Economies. Oxford: Oxford University Press.

Esping-Andersen, G. 2003. “Towards the Good Society, Once Again?” In Why We Need a New Welfare State, edited by G. Esping-Andersen. Oxford: Oxford University Press.

Esping-Andersen, G., and W. Korpi. 1987. "From Poor Relief to Institutional Welfare States: The Development of Scandinavian Social Policy." In The Scandinavian Model, edited by R. Eriksson. New York, NY: Armonk.

Finnemore, M., and K. Sikkink. 1998. "International Norm Dynamics and Political Change." International Organization 52 (4): 887-917. https://doi.org/10.1162/ 002081898550789.

Ford, M., and F. O. Andersson. 2016. "Organizational Failure in the Hollow State: Lessons from the Milwaukee Voucher Experience." International Journal of Public Administration 39 (11): 883-894. https://doi.org/10.1080/01900692.2015.1053613.

Ford, M. R., and F. O. Andersson. 2017. "Determinants of Organizational Performance in a Reinventing Government Setting: Evidence from the Milwaukee School Voucher Programme." Public Management Review 19 (10): 1519-37. https://doi.org/10.1080/ 14719037.2017.1296487.

Ford, M. R., and F. O. Andersson. 2019. "Taking Stock and Moving Forward: Lessons From Two Plus Decades of Research on the Milwaukee Parental Choice Program." Journal of School Choice 13 (2): 158-76. https://doi.org/10.1080/15582159.2017.1350085.

Ford, M. R., and D. M. Ihrke. 2018. "Third Party Governance Training and Voucher School Performance." Journal of School Choice 12 (3): 382-400. https://doi.org/10.1080/15582159. 2018.1490384.

Ford, M. R. 2015. “A Faith-Based Advantage?.” Nonprofit Management \& Leadership 26 (1): 91-104. https://doi.org/10.1002/nml.21142.

Friedman, M., and R. Friedman. 1980. Free to Choose. New York, NY: Harcourt, Brace, \& Janovich.

Friedman, M. 1955. "The Role of Government in Education." In Economics and the Public Interest, edited by R.A. Solo. 123-44. New Brunswick, NJ: Rutgers.

Gerring, J. 2007. “Is There A (Viable) Crucial-Case Method?.” Comparative Political Studies 40 (3): 231-53. https://doi.org/10.1177/0010414006290784.

Göçmen, I. 2013. "The Role of Faith-Based Organizations in Social Welfare Systems: A Comparison of France, Germany, Sweden, and the United Kingdom." Nonprofit and Voluntary Sector Quarterly 42 (3): 495-516. https://doi.org/10.1177/0899764013482046.

Grønbjerg, K. A. 2002. "Markets, Politics, and Charity: Nonprofits in the Political Economy.” In The Nature of the Nonprofit Sector, edited by J. S. Ott. Boulder; CO: L Westview Press.

Hammack, D. C., and H. Anheier. 2013. A Versatile American Institution. The Changing Ideals and Realities of Philanthropic Foundations. Washington, DC: Brookings Institution Press.

Henriksen, L. S., S. R. Smith, and A. Zimmer. 2012. "At the Eve Of Convergence? Transformations of Social Service Provision in Denmark, Germany, and the United States." VOLUNTAS: 
International Journal of Voluntary and Nonprofit Organizations 23 (2): 458-501. https://doi. org/10.1007/s11266-011-9221-5.

Hess, F. M. 2008. “The Supply Side of School Reform.” In The Future of Educational Entrepreneurship: Possibilities for School Reform, edited by F. M. Hess. 1-21. Cambridge, MA: Harvard Education Press.

Hicks, T. 2015. "Inequality, Marketization and the Left: School Policy in England and Sweden." European Journal of Political Research 54 (2): 326-42. https://doi.org/10.1111/1475-6765. 12086.

Hodgkinson, V. A., and M. S. Weitzman. 1993. From Belief to Commitment: The Community Service Activities and Finances of Religious Congregations in the United States. Washington, DC: Independent Sector.

Hollmer, M., and A. Bäckström. 2014. "Svenska kyrkan och välfärden. En undersökning av attityder." In Välfärdsinsatser på religiös grund. Förväntningar och problem, edited by A. Bäckström. Skellefteå: Artos och Norma bokförlag.

Hood, C. 1991. “A Public Management for All Seasons?.” Public Administration 69 (1): 3-19. https://doi.org/10.1111/j.1467-9299.1991.tb00779.x.

Jeppsson Grassman, E., and L. Svedberg. 2007. "Civic Participation in a Scandinavian Welfare State.” In State and Civil Society in Northern Europe. The Swedish Model Reconsidered, edited by L. Trägårdh. New York, NY: Berghahn Books.

Johansson, H., and M. Johansson. 2012. "From a Liberal to a Social Democratic Welfare State: The Policy Transfer of the UK Compact?." Nonprofit Policy Forum 3 (2): 3-24. https://doi.org/10. 1515/2154-3348.1057.

Kabalo, P. 2009. "A fifth Nonprofit Regime? Revisting Social Origins Theory Using Jewish Associational Life as a New State Model." Nonprofit and Voluntary Sector Quarterly 38 (4): 627-42. https://doi.org/10.1177/0899764009333333.

Kaboolian, L. 1998. "The New Public Management: Challenging the Boundaries of the Management vs. Administration Debate.” Public Administration Review 58 (3): 189-93. https://doi.org/10.2307/976558.

Kava, R. 2013. Milwaukee and Racine Parental Choice Programs. Madison, WI: Wisconsin Legislative Fiscal Bureau.

Kendall, J., and M. Knapp. 1996. The Voluntary Sector in the UK. Manchester: Manchester University Press.

Kettl, D. F. 2005. The Global Public Management Revolution, 2nd ed. Washington D.C.: Brookings Institution Press.

Klitgaard, M. B. 2007. "Do Welfare State Regimes Determine Public Sector Reforms? Choice Reforms in American, Swedish and German Schools." Scandinavian Political Studies 30 (4): 444-68. https://doi.org/10.1111/j.1467-9477.2007.00188.x.

Klitgaard, M. B. 2008. "School Vouchers and the New Politics of the Welfare State." Governance: An International Journal of Policy, Administration, and Institutions 21 (4): 479-98. https:// doi.org/10.1111/j.1468-0491.2008.00410.x.

Koinzer, T., R. Nikolai, and F. Waldow. 2017. "Private Schooling and School Choice as Global Phenomena: An Introduction." In Private Schools and School Choice in Compulsory Education, edited by T. Koinzer, R. Nikolai, and F. Waldow. Wiesbaden: Springer.

Kuhnle, S., and P. Selle. 1992. Government and Voluntary Organizations: A Relational Perspective. Avebury: Aldershot.

Lewin, L. 2014. Staten får inte abdikera - om kommunaliseringen av den svenska skolan. Betänkande av Utredningen om skolans kommunalisering. SOU 2014:5. Stockholm: Fritzes. 
Lieberman, M. 1986. Beyond Public Education. New York, NY: Praeger.

Lieberman, M. 1989. Privatization and Educational Choice. New York, NY: St. Martin's Press. Lundahl, L. 2005. "A Matter of Self-Governance and Control the Reconstruction of Swedish Education Policy: 1980-2003.” European Education 37 (1): 10-25. https://doi.org/10.1080/ 10564934.2005.11042375.

Lundström, T., and L. Svedberg. 2003. "The Voluntary Sector in a Social Democratic Welfare State - The Case of Sweden.” Journal of Social Policy 32 (2): 217-38. https://doi.org/10.1017/ s0047279402007006.

Lundström, T., and F. Wijkström. 1997. The Nonprofit Sector in Sweden. Manchester: Manchester University Press.

Lundström, T., and F. Wijkström. 2012. “Från röst till service: vad hände sen?.” In Civilsamhället i samhällskontraktet, edited by F. Wijkström. Stockholm: European Civil Society Press.

Maier, F., M. Meyer, and M. Steinbereitner. 2014. "Nonprofit Organizations Becoming BusinessLike: A Systematic Review.” Nonprofit and Voluntary Sector Quarterly 45 (1): 64-86. https:// doi.org/10.1177/0899764014561796.

Mann, C.-O., T. Einarsson, and F. Wijkström. 2014. Västerås stift i omförhandlingen av det svenska välfärdskontraktet. Stockholm: European Civil Society Press.

McEwan, P. J. 2002. "Public Subsidies for Private Schooling: A Comparative Analysis of Argentina and Chile." Journal of Comparative Policy Analysis: Research and Practice 4 (2): 189-216. https://doi.org/10.1080/13876980208412678.

Meyer, J. W., J. Boli, G. M. Thomas, and F. O. Ramirez. 1997. "World Society and the Nation State." American Journal of Sociology 103 (1): 144-81. https://doi.org/10.1086/231174.

Meyer, J. W. 2007. "Globalization. Theory and Trends." International Journal of Comparative Sociology 48 (4): 261-73. https://doi.org/10.1177\%2F0020715207079529.

Miner, B. 2013. Lessons from the Heartland: A Turbulent Half-Century of Public Education in an Iconic American City. NY: The New Press.

Montin, S. 1997. “New Public Management på svenska.” Politica 29 (3): 262-78. https://doi.org/ 10.7146/politica.v29i3.68141.

National Commission on Excellence in Education (NCEE). 1983. “A Nation at Risk: The Imperative for Educational Reform.” The Elementary School Journal 84 (2): 113-30. https://doi.org/10. $1086 / 461348$.

Neumayr, M., M. Meyer, M. Pospisil, U. Schneider, and I. Malý. 2009. "The Role of Civil Society Organizations in Different Nonprofit Regimes: Evidence from Austria and Czech Republic." In Civil Society in Comparative Perspective Comparative Social research, edited by B. Enjolras and K.-H. Sivesind, Vol. 26. Bingley: Emerald.

O'Neill, M. 2002. Nonprofit Nation: A New Look at the Third America. San Francisco, CA: JosseyBass.

Osborne, D., and T. Gaebler. 1993. Reinventing Government: How the Entrepreneurial Spirit is Transforming the Public Sector. New York, NY: Plume.

Osborne, D., and P. Plastrik. 1997. Banishing Bureaucracy: The Five Strategies for Reinventing. Reading, MA: Addison-Wesley.

Pinker, R. 1992. "Making Sense of the Mixed Economy of Welfare." Social Policy Administration 26 (4): 273-84. https://doi.org/10.1111/j.1467-9515.1993.tb00441.x.

Powell, M., ed. 2007. Understanding the Mixed Economy of Welfare. Bristol: Bristol University Press.

Prop. 1990/91:18. Ansvaret för skolan. Stockholm: Regeringskansliet.

Prop. 1991/92:95. Om valfrihet och fristående skolor. Stockholm: Regeringskansliet. 
Prop. 1995/96. Fristående skolor m.m. Stockholm: Utbildningsdepartementet.

Ragin, C. C. 1998. "Comments on "Social Origins Theory”." Voluntas 9 (3): 261-70. https://doi. org/10.1007/978-0-387-93996-4_619.

Ravitch, D. 2010. The Death and Life of the Great American School System. New York, NY: Basic Books.

Reuter, M., F. Wijkström, and J. von Essen. 2012. "Policy Tools Or Mirrors of Politics. GovernmentVoluntary Sector Compacts in the Post-Welfare State.” Nonprofit Policy Forum 3 (2): 1-22. https://doi.org/10.1515/2154-3348.1062.

Sahlin-Andersson, K. 2002. "National, International and Transnational Constructions of New Public Management." In New Public Management. The Transformation of Ideas and Practice, edited by T. Christensen, and P. Lægreid. Aldershot: Ashgate.

Salamon, L., and K. Anheier. 1998. "Social Origins of Civil Society: Explaining the Nonprofit Sector Cross-Nationally." Voluntas: International Journal of Voluntary and Nonprofit Organization 9 (3): 213-48. https://doi.org/10.1023/A:1022058200985.

Salamon, L.M. 1992. America's Nonprofit Sector: A Primer. New York, NY: The Foundation Center.

Selle, P., K. Strømsnes, L. Svedberg, B. Iblsen, and L. S. Henriksen. 2018. "The Scandinavian Organizational Landscape: Extensive and Different.” In Civic Engagement in Scandinavia. Volunteering, Informal Help and Giving in Denmark, Norway and Sweden, edited by L. S. Henriksen, K. Strømsnes, and L. Svedberg. Cham: Springer.

Silverman, R. M. 2012. "The Nonprofitization of Public Education: Implications of Requiring Charter Schools to be Nonprofits in New York." Nonprofit Policy Forum 3 (1): 1-22. https://doi.org/10.1515/2154-3348.1046.

Sivesind, K.-H., and J. Saglie. 2018. Promoting Active Citizenship. Markets and Choice in Scandinavian Welfare. New York, NY: Springer.

Sjöstrand, E. 2018. Shared Understandings Transformed. A Feld-Level Analysis of Changing State-Civil Society Relations. Stockholm: Stockholm School of Economics.

SOU 1993:16. Nya villkor för ekonomi och politik. Stockholm: Allmänna förlag.

Spigel, B. 2017. "The Relational Organization of Entrepreneurial Eco Systems." Entrepreneurship Theory and Practice 41 (1): 49-72. https://doi.org/10.1111/etap.12167.

Steinberg, R., and D. Young. 1998. "A Comment on Salamon and Anheier's "Social Origins of Civil Society”." Voluntas 9 (3): 249-60. https://doi.org/10.1023/A:1022010317823.

Stenholm, B. 1984. Skolledning: samverkan och medinflytande. Stockholm: Liber utbildningsförlag.

Svedberg, L., and L. E. Olsson. 2010. "Voluntary Organizations and Welfare Provision in Sweden: Is there Such a Thing?." In Third Sector Organizations Facing Turbulent Environments: Sports, Culture and Social Services in Five European Countries, edited by A. Zimmer and A. Evers. Baden Baden: Nomos Verlag.

Svenska Kyrkan. 2018. Medlemmar i Svenska kyrkan i förhållande till folkmängd. Uppsala: Svenska kyrkan.

Trägårdh, L. 2010. "Rethinking the Nordic Welfare State Through a Neo-Hegelian Theory of State and Civil Society." Journal of Political Ideologies 15 (3): 227-39. https://doi.org/10.1080/ 13569317.2010.513853.

Trydegård, G-B. 2001. Välfärdstjänster till salu - privatisering och alternativa driftsformer under 1990-talet. Välfärdstjänster i omvandling, SOU 2001:52. Stockholm: Regeringen.

Villadsen, K. 2007. "The Emergence of "Neo-Philanthropy": A New Discursive Space in Welfare Policy?.” Acta Sociologica 50 (3) 309-25. https://doi.org/10.1177/0001699307080938. 
Vlachos, J. 2011. “Friskolor i förändring.” In Konkurrensens konsekvenser. Vad händer med svensk välfärd?, edited by L. Hartman. Stockholm: SNS Förlag.

Wennström, J. 2019. "Marketized Education: How Regulatory Failure Undermined the Swedish School System." Journal of Education Policy Published online: 1-27. https://doi.org/10. 1080/02680939.2019.1608472.

West, A., and R. Nikolai. 2017. "The Expansion of "Private" Schools in England, Sweden and Eastern Germany: A Comparative Perspective on Policy Development, Regulation and Policy Goals And Ideas." Journal of Comparative Policy Analysis: Research and Practice 19 (5): 452-69. https://doi.org/10.1080/13876988.2016.1262549.

West, A. 2014. “Academies in England and Independent Schools (fristående skolor) in Sweden: Policy, Privatisation, Access And Segregation." Research Papers in Education 29 (3): 330-50. https://doi.org/10.1080/02671522.2014.885732.

West, A. 2017. "Private Schools in Sweden: Policy Development, Inequalities and Emerging Issues." In Private Schools and School Choice in Compulsory Education, edited by T. Koinzer, R. Nikolai, and F. Waldow. 67-79. New York, NY: Springer.

Wijkström, F. and S. Einarsson. 2018. "Comparing Swedish Foundations: A Carefully Negotiated Space Of Existence.” American Behavioral Scientist 62 (13): 1189-918. https://doi.org/10. $1177 / 0002764218773439$.

Wijkström, F., and T. Lundström, eds. 2002. Den ideella sektorn. Organisationerna i det civila samhället. Sober Förlag: Stockholm.

Wijkström, F., and A. Zimmer, eds. 2011. Nordic Civil Society at a Cross-Road: Transforming the Popular Movement Tradition. Baden-Baden: Nomos.

Wijkström, F. 1997. "The Swedish Nonprofit Sector in International Comparison.” Annals of Public and Cooperative Economics 68 (4): 625-63. https://doi.org/10.1111/1467-8292.00067.

Wijkström, F. 2011. “Charity Speak' and 'Business Talk'. The On-going (Re)Hybridization of Civil Society." In Nordic Civil Society at a Cross-Road: Transforming the Popular Movement Tradition, edited by F. Wijkström, and A. Zimmer. Baden-Baden: Nomos.

Wijkström, F. 2014. "Svenska kyrkan i ett omförhandlat samhällskontrakt.” In Välfärdsinsatser på religiös grund, edited by. A. Bäckström. Skellefteå: Artos och Norma Förlag.

Wijkström, F. 2016. "Slutna rum för nygamla dygder. Ett sällskapsliv på uppmarsch." In För det allmänna bästa. Ett kungligt sällskap mellan stat och marknad under 250 år: Kungl. Sällskapet Pro Patria 1766-2016, edited by E. Amnå. Stockholm: Atlantis.

Wijkström, F. 2017. "Nytt svängrum för filantropi och frivillighet." In Civilsamhället $i$ det transnationella rummet, edited by F. Wijkström, M. Reuter, and A. Emami. Stockholm: European Civil Society Press.

Wilkins, A., J. Collet-Sabé, B. Gobby, and J. Hangartner. 2019. "Translation of New Public Management: A Decentred Approach to School Governance In Four OECD Countries." Globalisation, Societies and Education 17 (2): 147-60. https://doi.org/10.1080/14767724. 2019.1588102.

Willander, E. 2019. The Religious Landscape of Sweden. Affinity, Affiliation and Diversity in the $21^{\text {st }}$ Century. Stockholm: Swedish Agency for Support to Faith Communities.

Witte, J. F., P. J. Wolf, J. M. Cowen, D. J. Fleming, and J. Lucas-McLean. 2008. MPCP Longitudinal Educational Growth Study Baseline Report. Fayetteville, AK: School Choice Demonstration Project at the University of Arkansas.

Witte, J. F. 2000. The Market Approach to Education: An Analysis of America's First Voucher Program. Princeton, NJ: Princeton University Press.

Wolfe, A. 1989. Whose Keeper. Berkeley, CA: University of California Press. 
Wuthnow, R. 2005. "New Directions in the Study of Religion and Economic Life.” In The Handbook of Economic Sociology, edited by N. J. Smelser, and R. Swedberg. 2nd ed. Princeton, NJ: Princeton University Press, 603-26.

Zimmer, A., and A. Evers. 2010. "How Do Third Sector Organizations Deal With Change? Perspective From Five Countries in Three Policy Fields." In Third Sector Organizations Facing Turbulent Environments: Sports, Culture and Social Services in Five European Countries, edited by A. Zimmer, and A. Evers. Baden Baden: Nomos Verlag. 